INTERDISCIPLINARIA ARCHAEOLOGICA NATURAL SCIENCES IN ARCHAEOLOGY

\title{
Dog Burial and Animal Bone Remains from the Human Graves in Prague-Zličín
}

\author{
Hana Nohálováa,b*, Jiř́i Vávraa, Milan Kuchař́ik ${ }^{\mathrm{a}}$ \\ ${ }^{a}$ Labrys, o.p.s. Hloubětínská 16/11, Prague 9, 19800, Czech Republic \\ ${ }^{b}$ Department of Geological Sciences, Faculty of Science, Masaryk University, Kotlárská 2, Brno, 61137, Czech Republic
}

\section{ARTICLE INFO}

\section{Article history:}

Received: $3^{\text {rd }}$ Juny 2016

Accepted: $21^{\text {st }}$ November 2016

\section{Key words:}

Prague-Zličín

dog burial

animal bones

bone tools

Migration Period

Vinařice group

\begin{abstract}
$A B S T R A C T$
We present an evaluation of research on zooarchaeological material from the skeletal burial ground of the Vinařická group of the Late Migration Period in Prague-Zličín. Attention is drawn to feature no. 1524, in which was found the burial of a dog whose radiocarbon date is consistent with the dating of the burial ground. The skeleton is of an older individual, probably female, in which was found a fracture of the right lower canine. The rest of the article considers the animal bones from the grave infillings, the dating of which is problematic. The bones are probably a residue and intrusion, having nothing to do with the burial rite, and it remains unclear how much they are related to zooarchaological evaluations of the Migration Period, the Roman Period, or the Early Middle Ages. Hence these results cannot be reliably used to reconstruct the subsistence strategies of populations in the Migration Period. Taphonomic phenomena associated with the activity of rodents are also discussed.
\end{abstract}

\section{Introduction}

The study has two main aims: firstly, to present an individual dog burial contemporary with the Migration Period human burials in Prague-Zličín; and secondly to discuss the origin and possible interpretation of the assemblage of animal bones and other remains recovered from the infill of the graves in this cemetery. The cemetery was excavated between 2005-2008 and is dated to the Migration Period - the $2^{\text {nd }}$ and $3^{\text {rd }}$ thirds of the $5^{\text {th }}$ century AD - and ascribed to the so-called Vinařická group and represents 173 documented inhumation graves: the largest graveyard of this epoch in Bohemia and one of the largest in central Europe. Its dating to the $5^{\text {th }}$ century $\mathrm{AD}$ is grounded on brooches, buckles, glass vessels, ceramics, different fittings and other metal objects. A belt buckle, a brooch and some other objects indicate an end of the burying around $500 \mathrm{AD}$. The character of the finds suggests a supra-regional importance for the cemetery and cultural relationships to Gaul, the Rhineland and regions

*Corresponding author. E-mail: hanka.uhl@gmail.com along the Danube, as well as to the North Sea (Vávra et al. 2009; 2012; Jiř́k et al. 2015).

\section{Material and methods}

The studied and presented zooarchaeological material comes from the infillings of 36 skeletal graves (Table 1) out of a total of 173 identified graves, and the separate feature of no. 1524 . The animal bones were obtained by hand-retrieval and flotation of the grave fillings. The zooarchaeological analysis was based on commonly-used methods and procedures. Relevant atlases and guides were used for the generic and anatomical determination of the osteological material (Schmid 1972; Červený et al. 1999; France 2009). Taxonomically-indeterminable material was sorted into size categories (VSS - very small size/rodents, SS - small size/ brown hare; SS-MS - small size to medium size/European beaver, dog; MS - medium size/sheep/goat, pig; MS-LS medium size to large size/pig/wild boar; LS - large size/ cattle, European red deer). Age was determined by the coalescence of epiphyseal bones (Reitz, Wing 2008) and 
Table 1. Distribution of bones and malacofauna in the graves (quantification after NISP).

\begin{tabular}{|c|c|c|c|c|}
\hline Grave no. & Number & Species & Part of skeleton & Total \\
\hline 19 & 2 & Sus domesticus & dens & 2 \\
\hline 24 & 6 & Ruminant & dens & 6 \\
\hline \multirow{3}{*}{41} & 11 & Sus domesticus & mandibula & \multirow{3}{*}{51} \\
\hline & 15 & Medium mammal & fragment of bone & \\
\hline & 25 & Sus domesticus & dens & \\
\hline \multirow{8}{*}{55} & 11 & Bos taurus & dens & \multirow{8}{*}{55} \\
\hline & 4 & Bos taurus & mandibula & \\
\hline & 3 & Undetermined mammal & fragment of bone & \\
\hline & 6 & Large mammal & fragment of bone & \\
\hline & 20 & Medium mammal & fragment of bone & \\
\hline & 2 & Bos taurus & humerus & \\
\hline & 1 & Bos taurus & phalanx I & \\
\hline & 8 & Small mammal-Medium mammal & fragment of bone & \\
\hline \multirow{3}{*}{56} & 4 & Bos taurus & humerus & \multirow{3}{*}{53} \\
\hline & 10 & Large mammal & costa & \\
\hline & 39 & Small mammal & fragment of bone & \\
\hline 60 & 1 & Ovis aries/Capra hircus & pelvis & 1 \\
\hline \multirow{3}{*}{63} & 1 & Sus domesticus & tibia & \multirow{3}{*}{68} \\
\hline & 16 & Medium mammal & fragment of bone & \\
\hline & 51 & Small mammal-Medium mammal & fragment of bone & \\
\hline \multirow{2}{*}{65} & 3 & Rodentia & dens & \multirow{2}{*}{17} \\
\hline & 14 & Small mammal & fragment of bone & \\
\hline 95 & 1 & Canis familiaris & metapodium & 1 \\
\hline \multirow{6}{*}{107} & 1 & Malacofauna & shell & \multirow{6}{*}{34} \\
\hline & 8 & Rodentia & dens & \\
\hline & 1 & Rodentia & tibia & \\
\hline & 1 & Rodentia & ulna & \\
\hline & 1 & Rodentia & mandibula & \\
\hline & 22 & Rodentia & fragment of bone & \\
\hline \multirow{6}{*}{121} & 1 & Sus domesticus & maxilla & \multirow{6}{*}{48} \\
\hline & 1 & Medium mammal & flat bone & \\
\hline & 1 & Medium mammal & costa & \\
\hline & 1 & Sus domesticus & dens & \\
\hline & 3 & Rodentia & dens & \\
\hline & 41 & Small mammal-Medium mammal & fragment of bone & \\
\hline 126 & 2 & Very small mammal & fragment of bone & 2 \\
\hline 127 & 2 & Rodentia & dens & 2 \\
\hline \multirow{6}{*}{133} & 1 & Bos taurus & mandibula & \multirow{6}{*}{75} \\
\hline & 10 & Large mammal & fragment of bone & \\
\hline & 1 & Bos taurus & metacarpus & \\
\hline & 15 & Large mammal & mandibula & \\
\hline & 23 & Large mammal & flat bone & \\
\hline & 25 & Large mammal & fragment of bone & \\
\hline \multirow{2}{*}{134} & 4 & Large mammal & long bone & \multirow{2}{*}{5} \\
\hline & 1 & Bos taurus & humerus & \\
\hline \multirow{8}{*}{136} & 1 & Bos taurus & talus & \multirow{8}{*}{146} \\
\hline & 6 & Bos taurus & mandibula & \\
\hline & 9 & Large mammal & flat bone & \\
\hline & 2 & Bos taurus & scapula & \\
\hline & 1 & Large mammal & vertebra & \\
\hline & 19 & Large mammal & long bone & \\
\hline & 1 & Medium mammal-Large mammal & flat bone & \\
\hline & 44 & Large mammal & fragment of bone & \\
\hline
\end{tabular}


Table 1. Distribution of bones and malacofauna in the graves (quantification after NISP). (Continuation)

\begin{tabular}{|c|c|c|c|c|}
\hline Grave no. & Number & Species & Part of skeleton & Total \\
\hline \multirow{12}{*}{$\begin{array}{c}\mathbf{1 3 6} \\
\text { (Continuation) }\end{array}$} & 13 & Ruminant & dens & \multirow{12}{*}{$\begin{array}{c}146 \\
\text { (Continuation) }\end{array}$} \\
\hline & 1 & Bos taurus & os centrotarsale & \\
\hline & 1 & Bos taurus & phalanx I & \\
\hline & 1 & Bos taurus & patella & \\
\hline & 3 & Bos taurus & mandibula & \\
\hline & 2 & Large mammal & pelvis & \\
\hline & 12 & Large mammal & flat bone & \\
\hline & 20 & Medium mammal-Large mammal & fragment of bone & \\
\hline & 1 & Bos taurus & femur & \\
\hline & 1 & Medium mammal & pelvis & \\
\hline & 1 & Sus domesticus & vertebra & \\
\hline & 7 & Medium mammal & fragment of bone & \\
\hline 138 & 3 & Undetermined mammal & fragment of bone & 3 \\
\hline \multirow{3}{*}{142} & 10 & Sus domesticus & dens & \multirow{3}{*}{74} \\
\hline & 63 & Medium mammal-Large mammal & fragment of bone & \\
\hline & 1 & Large mammal & long bone & \\
\hline 143 & 1 & Medium mammal & costa & 1 \\
\hline \multirow{12}{*}{146} & 9 & Bos taurus & mandibula & \multirow{12}{*}{90} \\
\hline & 1 & Bos taurus & axis & \\
\hline & 11 & Large mammal & mandibula & \\
\hline & 1 & Bos taurus & pelvis & \\
\hline & 1 & Large mammal & long bone & \\
\hline & 6 & Large mammal & fragment of bone & \\
\hline & 3 & Bos taurus & femur & \\
\hline & 2 & Bos taurus & atlas & \\
\hline & 4 & Bos taurus & dens & \\
\hline & 33 & Medium mammal-Large mammal & fragment of bone & \\
\hline & 4 & Bos taurus & scapula & \\
\hline & 15 & Large mammal & flat bone & \\
\hline 147 & 2 & Rodentia & dens & 2 \\
\hline 150 & 1 & Bos taurus & humerus & 1 \\
\hline \multirow{2}{*}{153} & 11 & Undetermined mammal & fragment of bone & \multirow{2}{*}{12} \\
\hline & 1 & Very small mammal & fragment of bone & \\
\hline \multirow{5}{*}{154} & 1 & Medium mammal-Large mammal & mandibula & \multirow{5}{*}{39} \\
\hline & 1 & Medium mammal & vertebra & \\
\hline & 1 & Rodentia & pelvis & \\
\hline & 19 & Rodentia & fragment of bone & \\
\hline & 17 & Undetermined mammal & fragment of bone & \\
\hline 155 & 2 & Very small mammal & fragment of bone & 2 \\
\hline \multirow{3}{*}{156} & 2 & Large mammal & long bone & \multirow{3}{*}{6} \\
\hline & 3 & Medium mammal-Large mammal & long bone & \\
\hline & 1 & Very small mammal & fragment of bone & \\
\hline \multirow{2}{*}{159} & 19 & Medium mammal & long bone & \multirow{2}{*}{20} \\
\hline & 1 & Small mammal-Medium mammal & flat bone & \\
\hline 161 & 1 & Medium mammal & long bone & 1 \\
\hline 162 & 7 & Rodentia & fragment of bone & 7 \\
\hline \multirow{5}{*}{163} & 1 & Cepaea & shell & \multirow{5}{*}{40} \\
\hline & 2 & Undetermined mammal & fragment of bone & \\
\hline & 1 & Lepus europaeus & dens & \\
\hline & 35 & Rodentia & fragment of bone & \\
\hline & 1 & Rodentia & mandibula & \\
\hline \multirow{2}{*}{164} & 3 & Rodentia & dens & \multirow{2}{*}{72} \\
\hline & 1 & Rodentia & tibia & \\
\hline
\end{tabular}


Table 1. Distribution of bones and malacofauna in the graves (quantification after NISP). (Continuation)

\begin{tabular}{|c|c|c|c|c|}
\hline Grave no. & Number & Species & Part of skeleton & Total \\
\hline \multirow{6}{*}{$\begin{array}{c}164 \\
\text { (Continuation) }\end{array}$} & 4 & Undetermined mammal & fragment of bone & \multirow{6}{*}{$\begin{array}{c}72 \\
\text { (Continuation) }\end{array}$} \\
\hline & 1 & Ruminant & dens & \\
\hline & 46 & Rodentia & fragment of bone & \\
\hline & 5 & Small mammal-Medium mammal & fragment of bone & \\
\hline & 1 & Rodentia & pelvis & \\
\hline & 11 & Rodentia & long bone & \\
\hline \multirow{3}{*}{165} & 1 & Rodentia & dens & \multirow{3}{*}{4} \\
\hline & 1 & Rodentia & mandibula & \\
\hline & 2 & Rodentia & long bone & \\
\hline 166 & 1 & Small mammal & fragment of bone & 1 \\
\hline 167 & 1 & Very small mammal & fragment of bone & 1 \\
\hline \multirow{2}{*}{174} & 2 & Very small mammal & fragment of bone & \multirow{2}{*}{3} \\
\hline & 1 & Very small mammal & long bone & \\
\hline 175 & 1 & Very small mammal & fragment of bone & 1 \\
\hline
\end{tabular}

the replacement and eruption of teeth (Červený et al. 1999). The age of the dog was determined by the state of dentition (Procházka 1994). The methodology for measurements was taken from von den Driesch (1976). Based on the length parameters of relevant bones, the heights at the withers were calculated (Driesch, Boessneck 1974). The breed of dog was determined by Wagner (1930). All measurements were taken using a digital calliper $300 \mathrm{~mm} / 0.01 \mathrm{~mm}$. Measured values are stated in millimetres $(\mathrm{mm})$. Taphonomic and anthropogenic interventions were also observed (Lyman 1994). The morphological description of the skeletal elements is based on Najbrt (1980).

\section{Results}

\subsection{Dog burial}

Feature no. 1524 with the dog skeleton was located at the north-eastern edge of the explored area, northeast of the burial ground of the Migration Period (Figure 1). The distance between the feature and the nearest grave no. 138 was $96 \mathrm{~m}$. Due to the location of the feature at the edge of an unearthed area, we have only a partial idea about the surrounding terrain and its situation. The building is surrounded by two rows of stake or pillar pits, oriented approximately in a northwestsoutheast direction, and are likely to represent the floor plan of a prehistoric above-ground structure, stratigraphically older than feature no. 1524, which is in superposition with one stakehole. This above-ground construction, according to the field conditions, had already vanished by the time of the original making of feature no. 1524 and the burial of the $\mathrm{dog}$, and therefore it is probably unrelated to the feature. The terrain of most of the vicinity of feature no. 1524 remains uncovered, and therefore we have no further information about it.

The skeleton of the dog was placed in the western part of an approximately rectangular oblong pit, with dimensions of
$2.2 \times 1.2 \mathrm{~m}$ and a depth of about $0.2 \mathrm{~m}$ (after soil removal), and oriented by its longer axis in an east-west direction, just like the individual human graves (Figure 2). However, the shape of the pit does not correspond with the shapes of the other burial pits: firstly, it is much shallower than the other graves, which have an average depth of $1.2 \mathrm{~m}$, and does not contain the typical peripheral ledges or steps at the bottom. The location of the skeleton at the edge of a relatively long pit, without any further archaeological findings, is a distinctive feature, which prompts the question of whether there was anything else placed in the pit along with the dog, and possibly leaving some archaeological trace. There were no traces of any burial box next to the dog skeleton. Below the skeleton, in the bottom of the feature the rest of one posthole was found, which belongs to the previously mentioned two rows of postholes near the feature. The skeleton of the dog partially overlaps the posthole and is unimpaired, so the stakehole cannot be younger than feature no. 1524 and the burial of the dog. Next to the dog skeleton, a fragment of the first cervical vertebra from a cow (Bos taurus) was found. Because of the absence of ceramic material in the infilling of the feature, dating was obtained by a ${ }^{14} \mathrm{C}$-radiocarbon dating from the skeleton of the dog. For this purpose, a right calcaneus weighing $5 \mathrm{~g}$ was removed. The sample was analysed in the Radiocarbon Laboratory, Poznan (Poz-64641), giving us the date of $1550 \pm 30 \mathrm{BP}$ (Table 2). After data calibration the dating was shown to fall into a small radiocarbon plateau, hence its dating is not completely reliable. Due to the archaeological situation and radicarbon dating, it can be assumed that the dog skeleton belongs to the Migration Period.

The nearly complete skeleton of the adult dog (Canis familiaris) was examined; it had been placed on its right side, with his head to the south and feet to the east. From the position of the skeleton, it is obvious that the animal had been carefully laid into the feature, not thrown (Figure 3). Due to the weather conditions, the skeletal remains were in very 
IANSA $2016 \bullet V I I / 1 \bullet \quad 71-86$

Han Nohálová, Jiři Vávra, Milan Kuchařik: Dog Burial and Animal Bone Remains from the Human Graves in Prague-Zličin

(all:

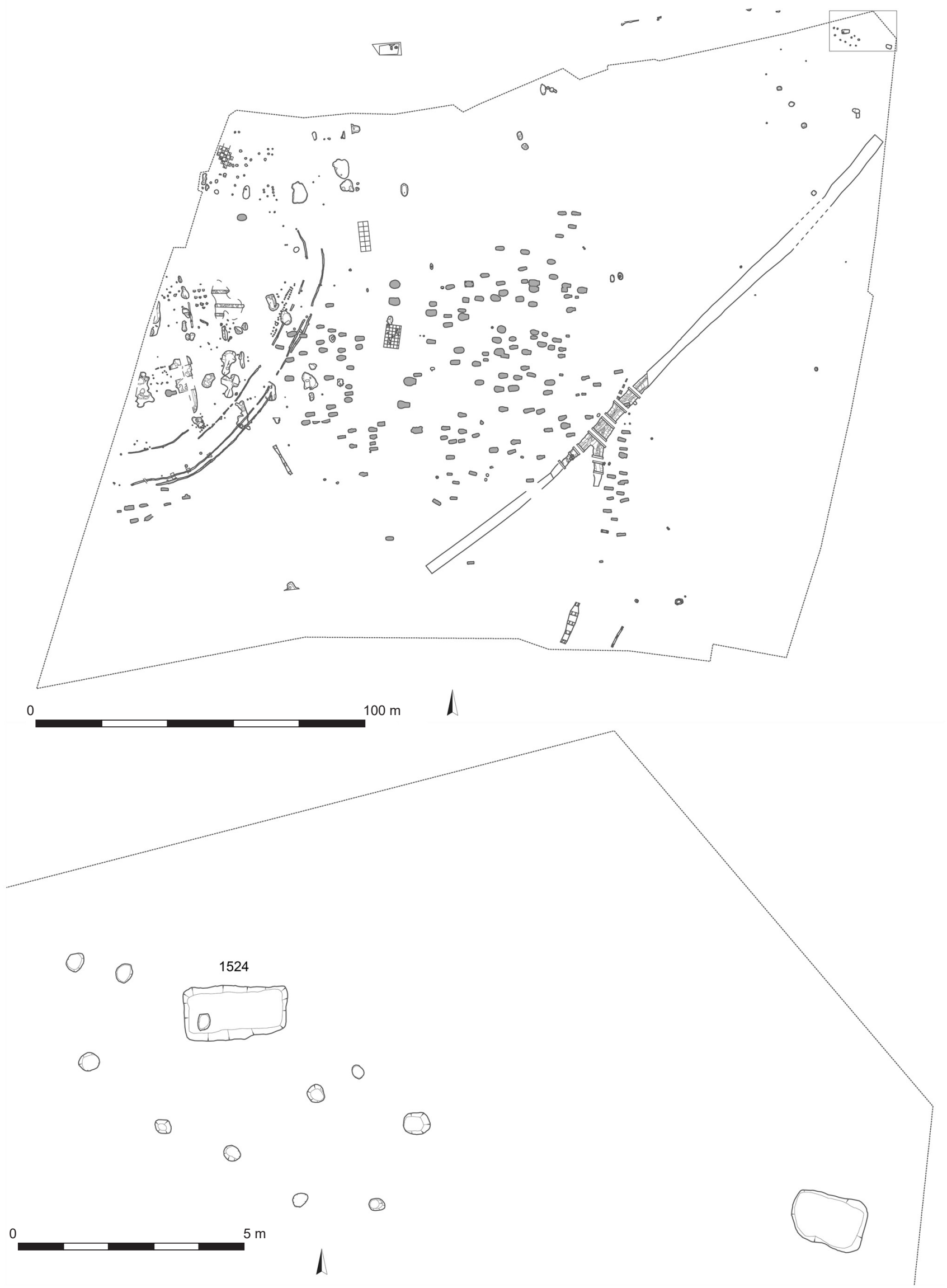

Figure 1. The overall research plan and the relationship of feature no. 1524 to the burial ground.

75 


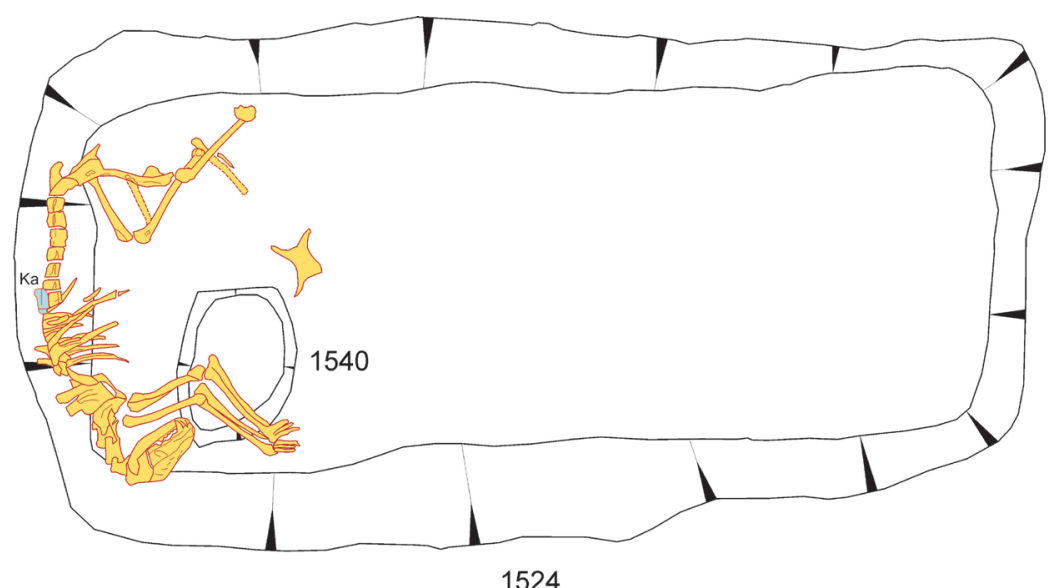

Figure 2. Feature no. 1524 with the dog burial.
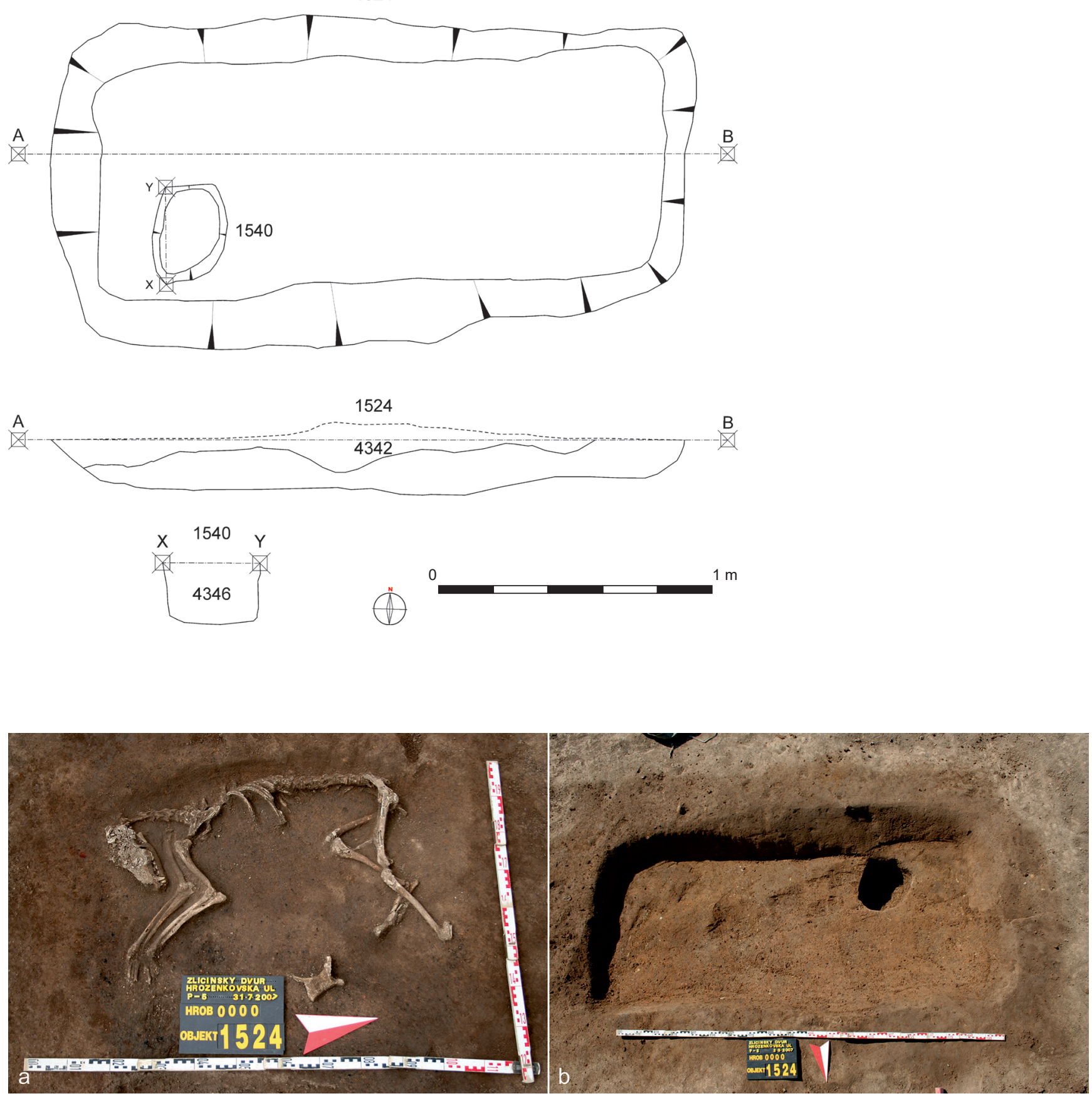

Figure 3. Position of the dog skeleton in feature no. 1524 (a) and the pillar pit at the bottom of the feature (b). 
Table 2. Radiocarbon dating of the calcaneus of dog.

\begin{tabular}{ccccc}
\hline OxCal v4.2.3 Bronk Ramsey (2013); r:5; IntCal13 atmospheric curve (Reimer et al. 2013) & \\
\hline I.D. & Sample & 14C age & 1 sigma & 2 sigma \\
\hline Poz-64641 & Dog-calcaneus & 1550 $\pm 30 \mathrm{BP}$ & 430AD to 550AD & 423AD to 574AD \\
\hline
\end{tabular}

Table 3. Biometry of bones (in $\mathrm{mm})$. * Indicative measure (damaged bone).

\begin{tabular}{ll}
\hline \multicolumn{1}{c}{ Part of skeleton } & \multicolumn{1}{c}{ Biometry (in mm) } \\
\hline Right mandibula (c, p1 - m3) & $m 1: \mathbf{L}-23.05, \mathbf{B}-10.17 ; m 2: \mathbf{L}-9.26, \mathbf{B}-7.67 ; m 3: \mathbf{L}-5.49, \mathbf{B}-4.87 ; \mathbf{7}-87.4 ; \mathbf{8}-81.06 ; \mathbf{9}-74.43 ;$ \\
& $\mathbf{1 0}-38.47 ; \mathbf{1 1}-44.08 ; \mathbf{1 2}-36.48 ; \mathbf{1 3}-22.96 ; \mathbf{1 9}-28.45 ; \mathbf{2 0}-22.07$ \\
& $m 1: \mathbf{L}-22.33, \mathbf{B}-9.5 ; m 2: \mathbf{L}-9.34, \mathbf{B}-7.67 ; m 3: \mathbf{L}-5.72, \mathbf{B}-4.89 ; \mathbf{8}-81.22 ; \mathbf{9}-74.33 ; \mathbf{1 0}-38.19 ;$ \\
Left mandibula (c, p1 - m3) & $\mathbf{1 1}-44.48 ; \mathbf{1 2}-36.24 ; \mathbf{1 3}-23.01 ; \mathbf{1 9}-28.99 ; \mathbf{2 0}-22.44$ \\
Right maxilla (P2 - M2) & $P 4: \mathbf{L}-18.36, \mathbf{G B}-11.39, \mathbf{B}-8.48 ; M 1: \mathbf{L}-14.14, \mathbf{B}-15.43 ; M 2: \mathbf{L}-7.41, \mathbf{B}-10.13 ; \mathbf{1 6}-21.24$ \\
\hline
\end{tabular}

poor state of preservation (Figure 4). However, if the state of preservation allowed, they were subjected to morphometric analysis (Table 3). There were 508 fragments obtained in varying stages of conservation, with the predominance of bones being of the skull and jaws, limbs and vertebrae.
A dog's age can be determined fairly accurately during its puppy years on the basis of the exchange of milk teeth for permanent teeth. In the case of the Zličín finding, it is a dog with complete permanent teeth, in which case it is possible to determine its age according to the stage of wear of the
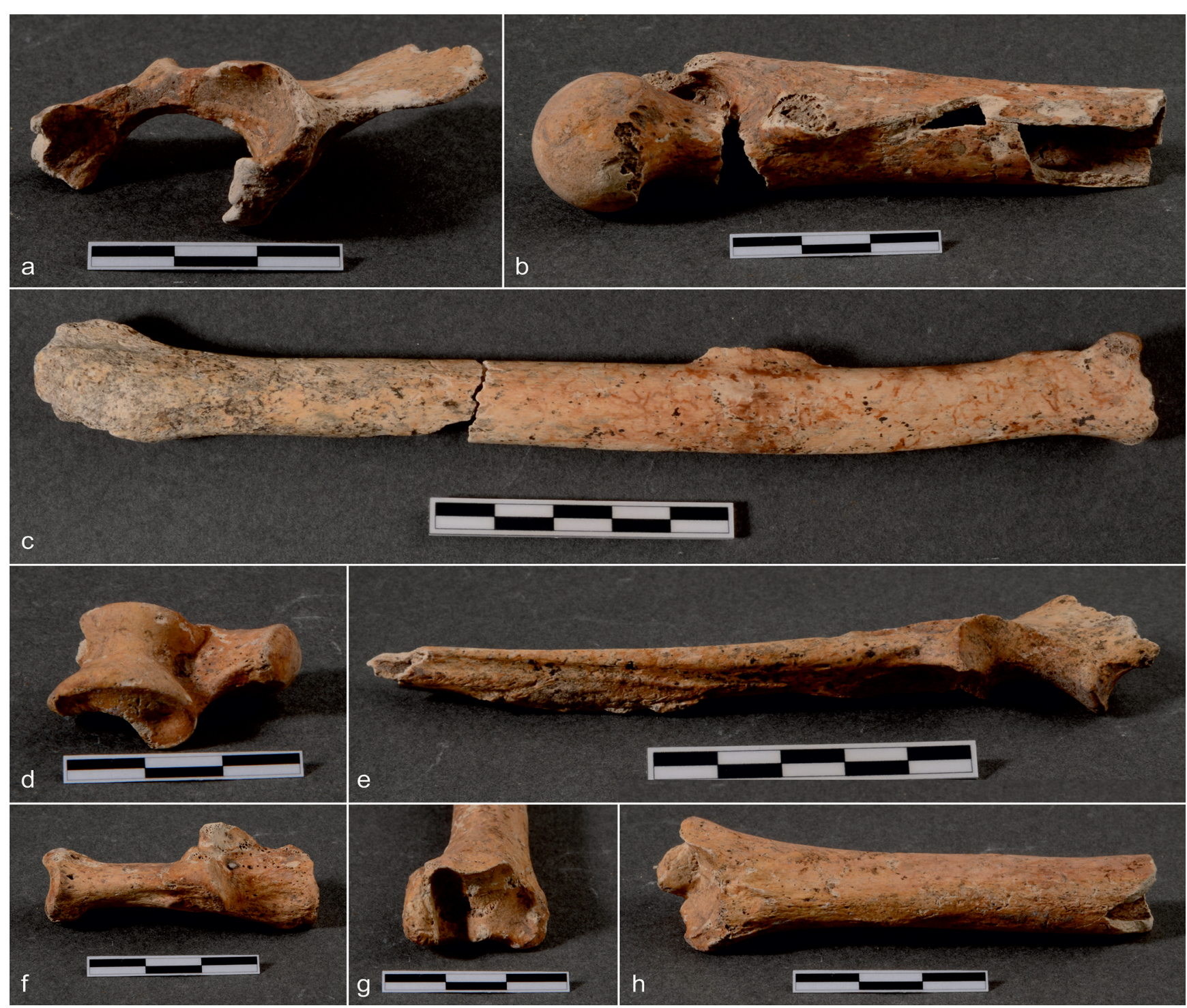

Figure 4. The better preserved skeletal fragments of the dog skeleton. $\mathrm{a}$ - atlas, $\mathrm{b}-$ femur, $\mathrm{c}$ - radius, $\mathrm{d}-$ talus, $\mathrm{e}-\mathrm{ulna}, \mathrm{f}-$ calcaneus, $\mathrm{g}, \mathrm{h}-$ tibia. 


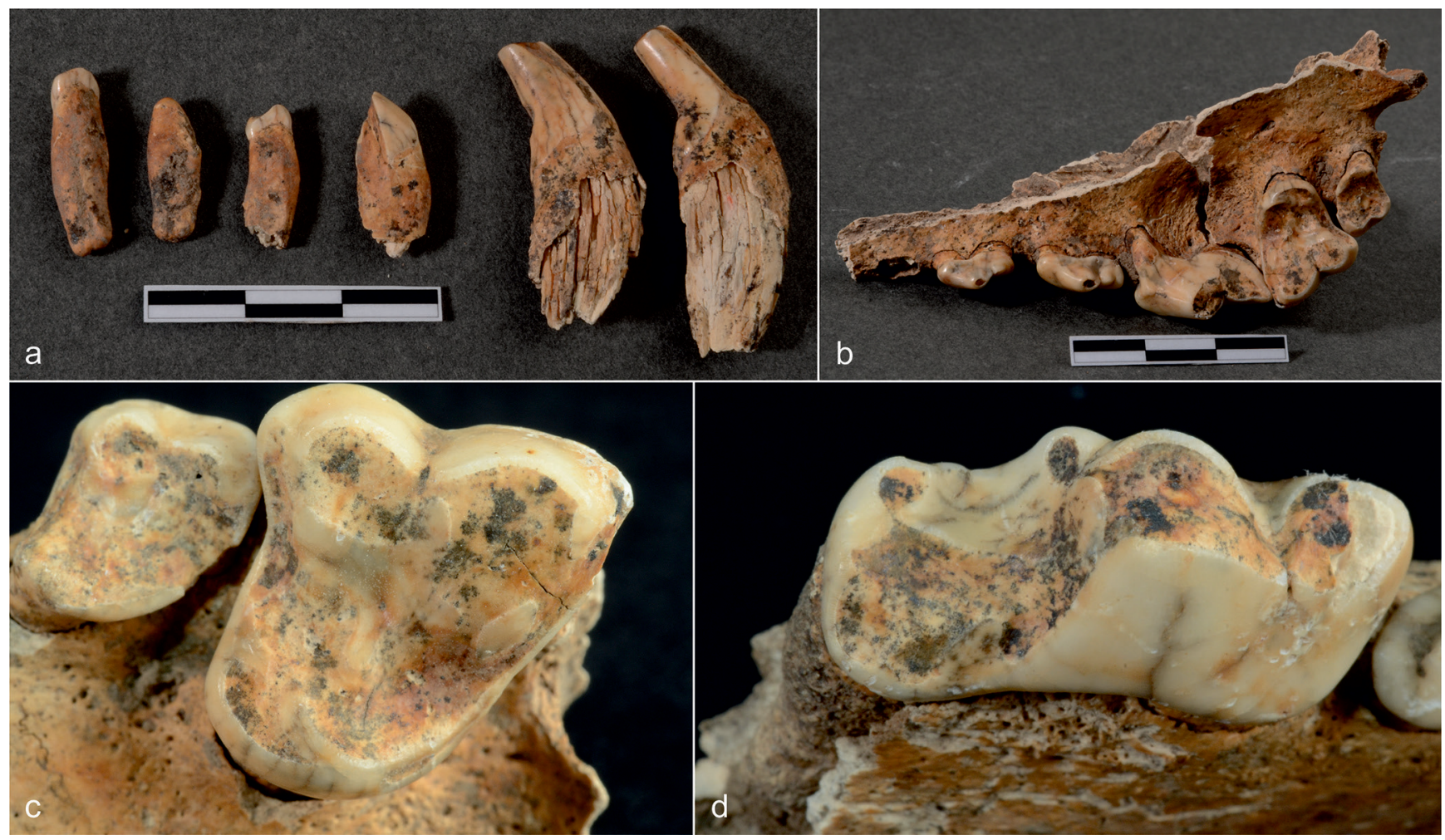

Figure 5. Teeth of the dog. a - incisors and canines, $\mathrm{b}$ - maxilla with P2-M2, c-detail of M1-M2, d-detail of m1.

teeth, particularly the incisors and canines (Figure 5). On its incisors it is possible to see elimination of the dental crown cusps, which continues in the abrasion of the incisor bodies and their contraction. This occurs roughly at the age of six years in an individual. The canines are also abraded, which generally happens from the age of five years. By comparing the teeth of the Zličín dog with the teeth of present-day dogs, we can say that it was a dog older than six years, and, according to the stage of abrasion, probably even older than ten years. However, it is also necessary to consider the dog's
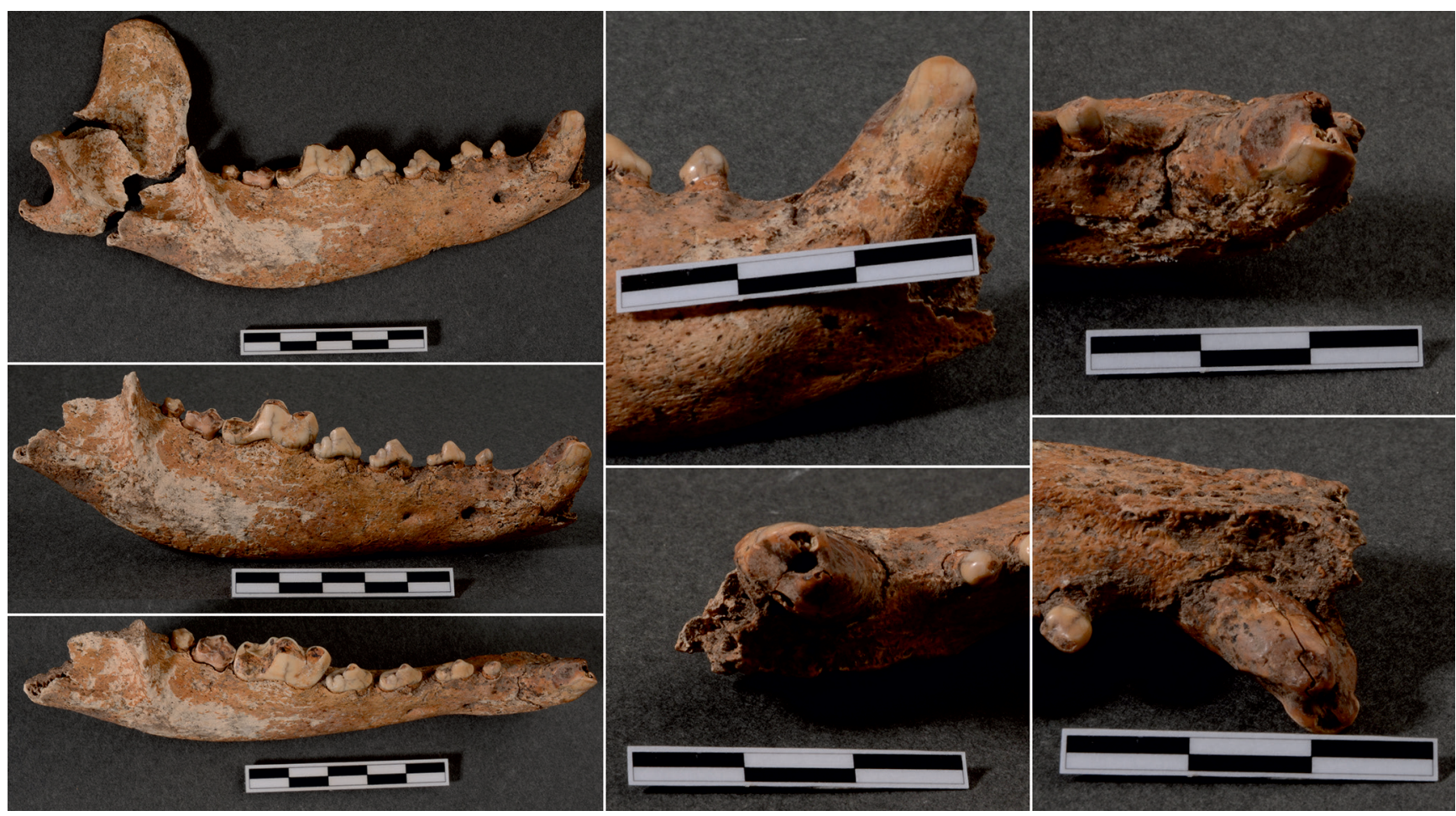

Figure 6. The right lower jaw with a pathological canine. 


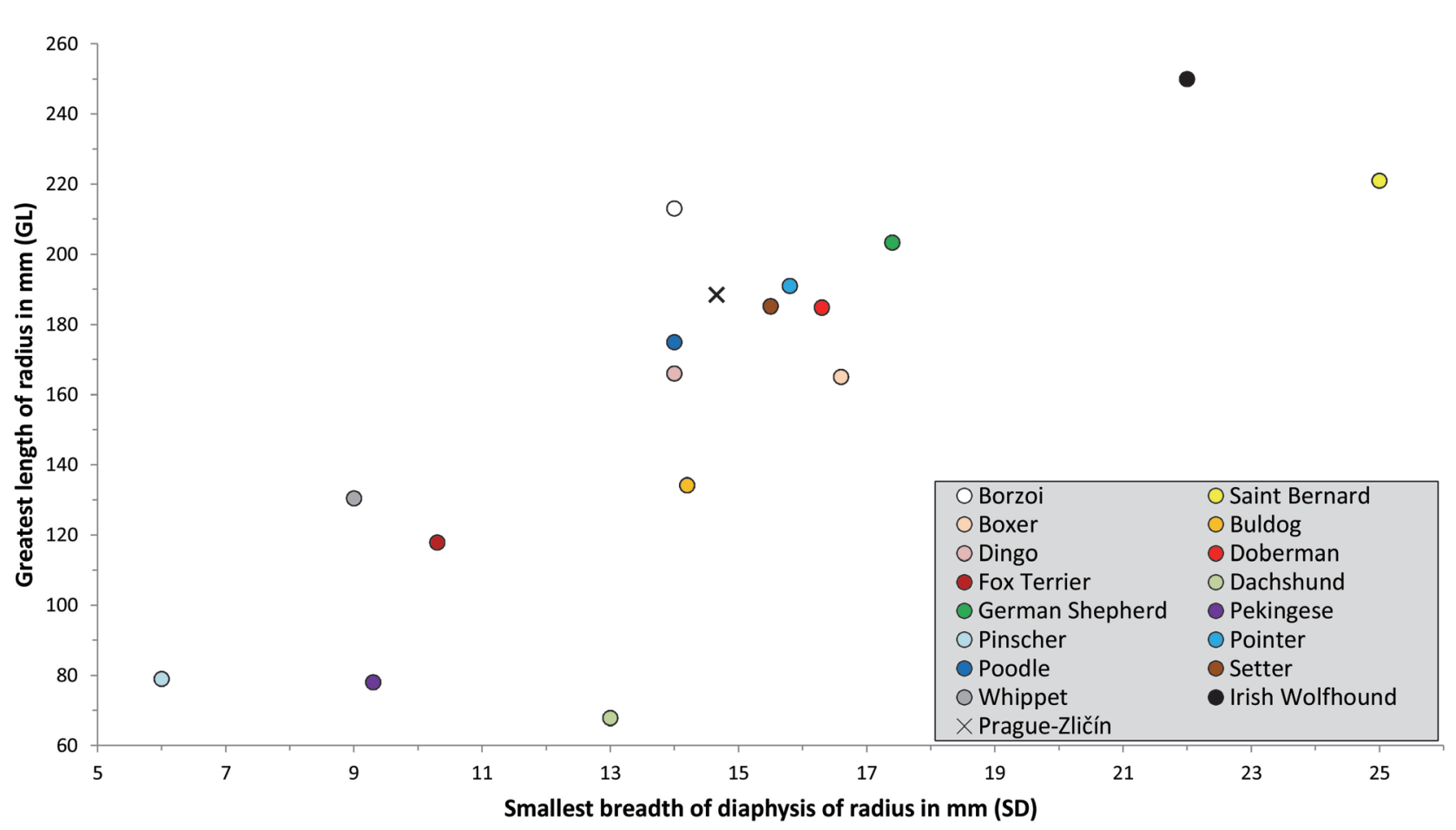

Figure 7. Correlation of the length and width of the radius of the Zličín dog with present breeds.

diet, environment and genetic make-up according to the breed.

In the bottom right canine tooth, a crown fracture was found with an exposed pulp cavity (Figure 6). This exposed pulp must have led to the capture of saliva and food debris that could thus have caused the infection of the tooth. An inflammation permeating the whole root had caused an increased deposition of cement at the root of the tooth (hypercementosis). The angled edges are abraded; the individual must have survived this injury by a few months or years.

The canine could have been broken as a result of picking up hunted prey, chewing on large hard bones, or in a skirmish with other dogs. It may also have been a secondary phenomenon due to the pathological changes in the teeth, resulting from excessive abrasion or caries.

Based on the length of the right radius (GL - 188.46 $\mathrm{mm}$ ) the height at the withers was calculated to be $62 \mathrm{~cm}$. Comparing the length and width dimensions of the radius with today's breeds, the dog from Prague-Zličín corresponds approximately to a Setter or Pointer (hunting breeds; Figure 7).

The sex of a dog can be recognized on the basis of the baculum (os penis). Neither this bone nor its fragments were found, so it is possible to presume that it was a female. There were no traces of human interaction discovered, yet the cause of the death of the animal cannot be clearly determined. In the case of a natural death, it would be a death due to age. However, blood poisoning, which could have come from the fracture of the canine tooth, also cannot be ruled out.

\subsection{Analysis of animal bones from human graves}

The studied assemblage consists of 944 bones and 2 malacofauna fragments obtained from various depths and contexts within the infill of the human graves. The animal bones were highly fragmented and preserved in poor condition, mostly due to the chemistry of the bedrock and the high moisture content of the sediments. Among the domestic mammals identified there were: cattle (Bos taurus), pig (Sus domesticus), sheep/goat (Ovis aries/Capra hircus) and dog (Canis familiaris). Among the wild animals there was evidence of brown hare (Lepus europaeus). Besides these taxa, the bones of rodents (Rodentia sp. indet.), unspecified taxa of ruminants (cattle/sheep/goat) and shells of malacofauna were found (Figure 8). The majority of the material were the remains of cattle $(21.0 \%)$ and pigs $(16.5 \%)$. The bones of small ruminants (sheep/goat) accounted for only $0.3 \%$ of the determined material. This is partly due to the preservation of the material but also due to the use of an intermediate category of "ruminants", where the fragments of selenodont teeth were placed. One fragment belonged to a $\operatorname{dog}(0.3 \%)$. The same percentage $(0.3 \%)$ was found for wild taxa - brown hare, Cepaea and an unidentified malacofauna. When it came to size categories, the bones of large mammals dominated $(34.2 \%)$.

A large part of the investigated set from Prague-Zličín were the bones of rodents $(54.6 \%)$ : they had inhabited the excavated areas for a long time and damaged the fillings of graves by their activity. This was documented in many of the graves by the marks left behind after clogged burrows. Moreover, in several graves, new, still unclogged burrows 


\section{Domestic/wild animals (NISP = 315)}

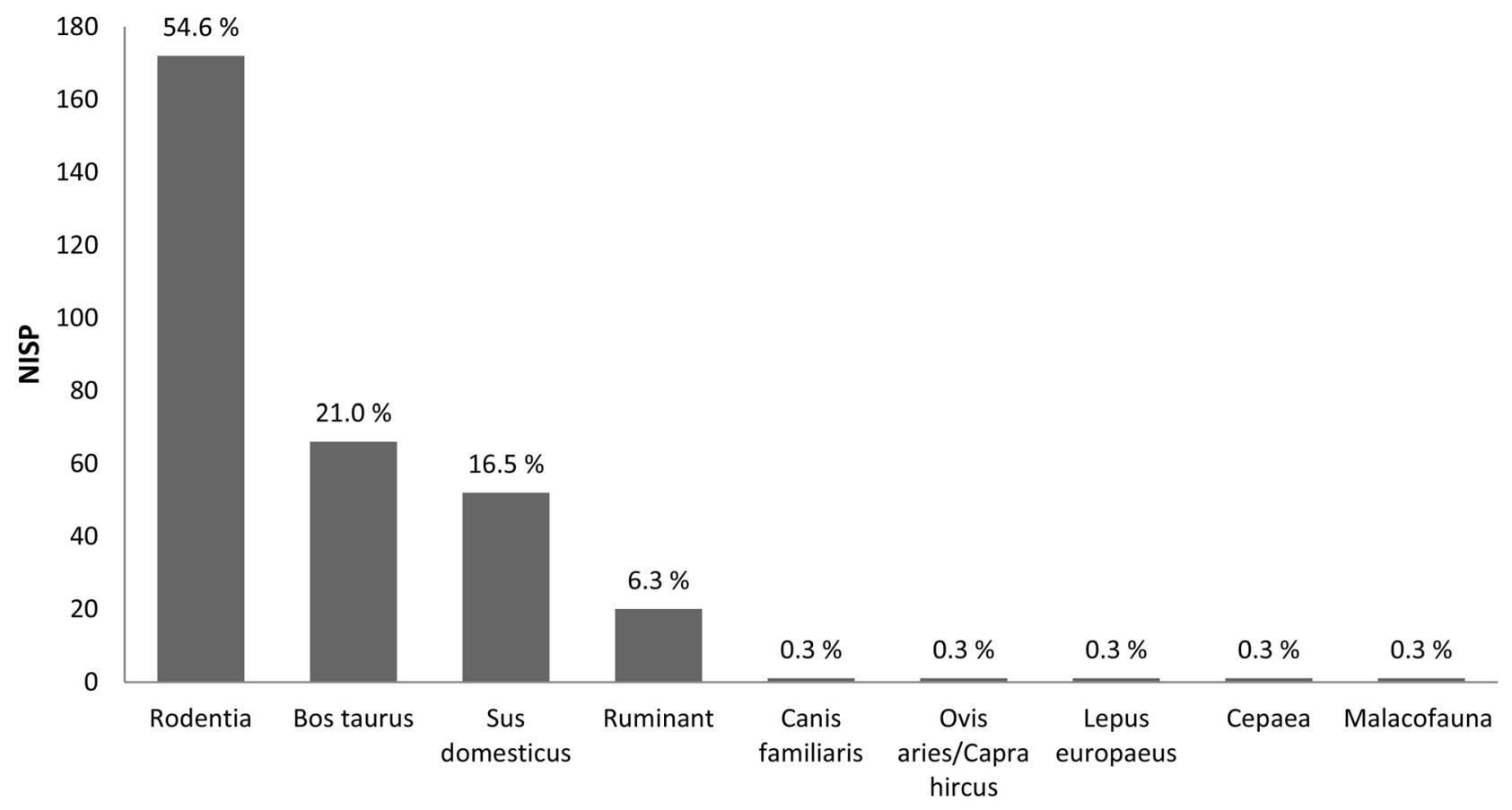

Figure 8. Incidence of domestic and wild species (quantification after NISP).

were found. In these manifestations of field activity, it was clearly apparent that, when digging their burrows, the rodents preferred the softer infillings of graves to the hard surrounding subsoil. They often dug their tunnels along the border area of the grave pit and subsoil, even following bends and corners. It can be presumed that the rodents could already have been active in the graves during the time there were hollow spaces inside the wooden coffins, before the wood had decayed. Rodents' access to the graves, particularly in the area of the deceased's body, had also been facilitated

Table 4. Representation of anatomical parts of individual species (quantification after NISP).

\begin{tabular}{|c|c|c|c|c|c|c|}
\hline & Bos taurus & Sus domesticus & Ovis aries/Capra hircus & Canis familiaris & Lepus europaeus & Total \\
\hline Maxilla & & 1 & & & & 1 \\
\hline Mandibula & 23 & 11 & & & & 34 \\
\hline Dens & 15 & 38 & & & 1 & 54 \\
\hline Atlas & 2 & & & & & 2 \\
\hline Axis & 1 & & & & & 1 \\
\hline Vertebra & & 1 & & & & 1 \\
\hline Scapula & 6 & & & & & 6 \\
\hline Humerus & 8 & & & & & 8 \\
\hline Metacarpus & 1 & & & & & 1 \\
\hline Pelvis & 1 & & 1 & & & 2 \\
\hline Femur & 4 & & & & & 4 \\
\hline Patella & 1 & & & & & 1 \\
\hline Tibia & & 1 & & & & 1 \\
\hline Talus & 1 & & & & & 1 \\
\hline Tarsale & 1 & & & & & 1 \\
\hline Metapodium & & & & 1 & & 1 \\
\hline Phalanx I & 2 & & & & & 2 \\
\hline Total & 66 & 52 & 1 & 1 & 1 & 121 \\
\hline
\end{tabular}


Table 5. Biometry of the well preserved bones (in $\mathrm{mm}$ ).

\begin{tabular}{lll}
\hline \multicolumn{1}{c}{ Species } & \multicolumn{1}{c}{ Part of skeleton } & \multicolumn{1}{c}{ Biometry (in mm) } \\
\hline Cattle & $\mathrm{m} 3$ & $\mathbf{L}-32,38 ; \mathbf{B}-13,91$ \\
Cattle & humerus & $\mathbf{B T}^{*}-57,20$ \\
Cattle & mandibula $(\mathrm{p} 3-\mathrm{m} 3)$ & $M 3: \mathbf{L}-30,35, \mathbf{B}-11,96 ; M 2: \mathbf{L}-21,83, \mathbf{B}-11,78 ; M 1: \mathbf{L}-19,83, \mathbf{B}-11,75 ; 8-75,56$ \\
Cattle & mandibula $(\mathrm{p} 3-\mathrm{m} 2)$ & $M 2: \mathbf{L}-24,51, \mathbf{B}-14,09 ; M 1: \mathbf{L}-20,67, \mathbf{B}-13,81$ \\
Cattle & metacarpus & $\mathbf{B p}-55,78, \mathbf{S D}-32,02 ; \mathbf{B d} *-46,33 ; \mathbf{G L} *-181,89$ \\
Cattle & os centrotarsale & $\mathbf{G B}-61,65$ \\
Cattle & mandibula (p4-m3) & $m 3: \mathbf{L}-37,12, \mathbf{B}-16,06 ; m 2: \mathbf{L}-25,35, \mathbf{B}-16,02 ; m 1: \mathbf{L}-21,84, \mathbf{B}-15,18$ \\
Pig & maxilla (P3-M3) & $M 2: \mathbf{L}-20,88, \mathbf{B}-15,55 ; M 1: \mathbf{L}-16,7, \mathbf{B}-12,74 ; M 3: \mathbf{L}-29,49, \mathbf{B}-18,76$ \\
\hline
\end{tabular}
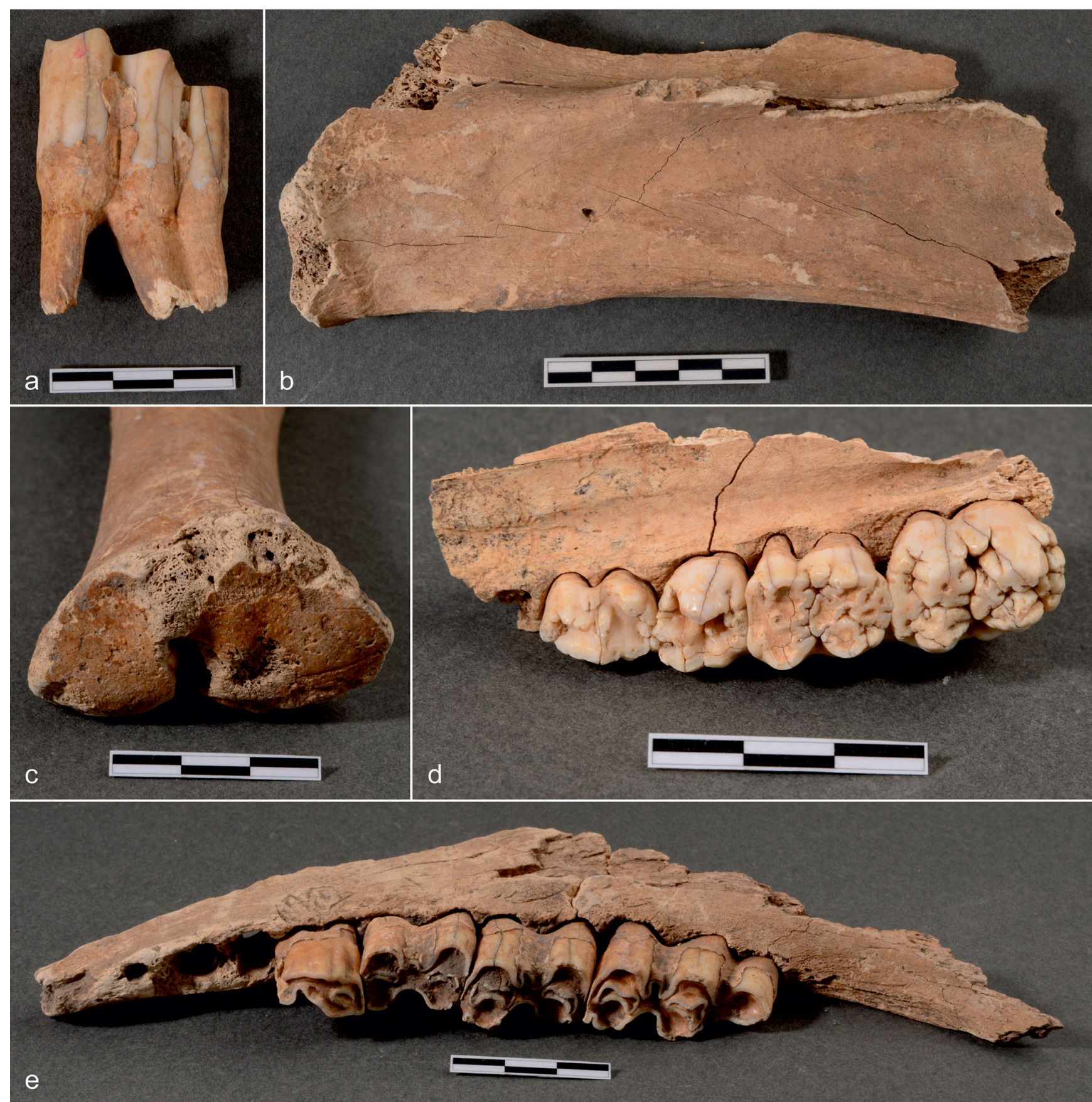

Figure 9. The better preserved fragments of bones from the infilling of the graves. a $-\mathrm{m} 3$ (Bos taurus), $\mathrm{b}-\mathrm{scapula}($ Bos taurus) $\mathrm{c}-$ metacarpus $($ Bos taurus), $\mathrm{d}$ - maxilla with P3-M2 (Sus domesticus), e - mandibula with p4-m3 (Bos taurus). 
by secondary excavations (digging due to looters' shafts). Through their activity, rodents could have disrupted parts of the burial at various times. In at least one grave (no. 162), the secondarily-displaced parts of the human skeleton can be explained as being the result of rodent activity. In one case, the burrow of a rodent damaged the glass container wall in the niche.

\subsubsection{Metrics, preservation, age}

The osteological assemblage of animal remains consist mostly of small bone fragments that could not be anatomically classified (63.7\%). Fragments of long bones (femur, humerus), flat bones such as the pelvis or scapula, or teeth released from alveoli, were also well represented (36.0\%). In general, the material represents skeletal material in which the bones appear more or less rich in muscle mass and where the locality was probably not only supplied by selected portions of animal skeletons (Table 4). The material is extensively damaged, so entire bones are almost never preserved, except for limb autopodia. Better preserved bone fragments were subjected to morphometric analysis (Table 5; Figure 9). The only complete bone in the set was the metacarpal bone of a cattle, on the basis of which the approximate height at the withers was calculated to be $112.4 \mathrm{~cm}$, using Matolcsi's coefficient. It is a rather small size for a cattle.

As mentioned, bone surfaces had been considerably disrupted by the weather conditions of the surrounding geological terrain. There were traces of the roots of plants and gnawing traces (canines and rodents) observed on the bones. Traces of human intervention on the bones were not found due to reduction by the soil environment and bone decay after picking.

Of the major economic mammals, the age composition of individuals was only determined for cow and pig. In the graves' skeletal material two specimens of cow older than 1.5 years were determined, two of them were older than 28 months and one younger than 42 months at the time of slaughter. In the case of pig, there was one specimen older than 22 months, and another 17-22 months old at the time of slaughter.

\subsubsection{Bone tools}

Nine Zličín graves (no. 3, 35, 54, 95, 97, 108, 113, 136 and 176) contained everyday objects - combs made of bone

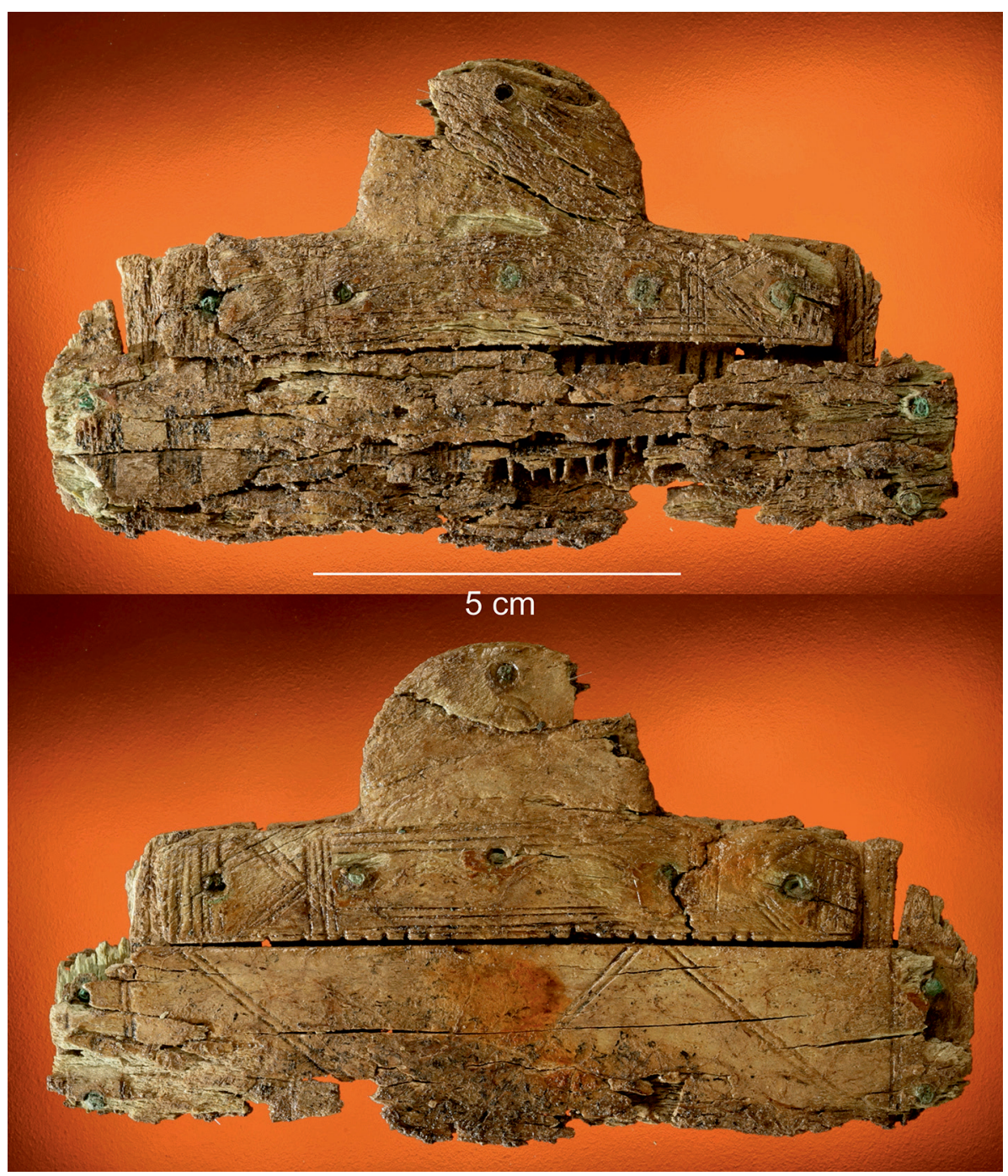

Figure 10. An antler comb with a linguiform handle with a protective sleeve for the teeth from grave no. 113, with a burial of a man aged 45-50 years. Photo: Martin Frouz. 

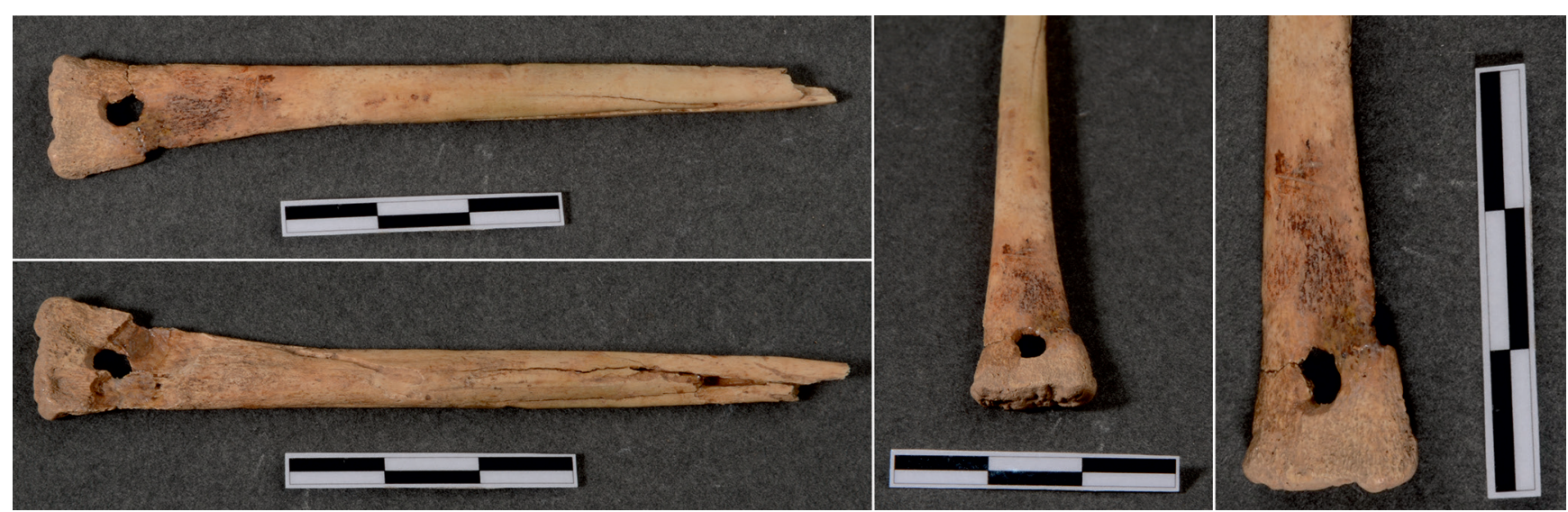

Figure 11. Bone awl from grave no. 142.

or antler. The most interesting of these comes from grave no. 113 , the comb being relatively well preserved, including the protective case for the teeth (Figure 10). At this burial ground, comb shapes with a triangular or linguiform handle prevail. In all cases, these are triple layer combs made from a composition of several parts, connected by bronze rivets (Jiřík, Vávra 2015, 174). In grave no. 142, a bone awl was found, made from the long bone of a medium-sized mammal (Figure 11). A unique finding is a shoe buckle with a frame made of bone or antler (grave no. 152). Due to the abundance of grave goods, we can assume that these tools are also associated with social status within the population.

\subsubsection{Taphonomy and dating of faunal remains}

For an interpretation of the animal bones from the graves in Prague-Zličín one must bear in mind their problematic dating; especially, but not exclusively, those present within the looters' shafts. Well-datable archaeological finds of cultural material indicate that pottery fragments from other archaeological periods of agricultural prehistory prevail. We think that these finds penetrated from the surface layers of the surrounding terrain to the fillings of graves or to secondary excavations, in a gradual process of infilling due to erosion. As a result of this process, some animal bones from older periods could have ended up in the graves. Dating of the animal bones was performed in the Radiocarbon Laboratory in Poznan; however, only on two fragments of long bones of a medium-sized mammal from the infilling of grave no. 55 (Poz-64644) and no. 142 (Poz-64646). Sample Poz-64644 gave the date of $1505 \pm 30 \mathrm{BP}$, the calibrated range of date (Table 6) being consistent with the overall archaeological dating of the burial ground, and its expected duration of use of 60 to 100 years (Víšková et al. 2012). Sample Poz-64646, along with other macro-botanical material in the graves, is considered as contamination (see Š́lková et al. 2016). For the above reasons, one must expect a wide range of dating for the bones of rodents, ranging from the period historically identical to that of the formation of the graves up to the recent period.

\section{Discussion}

\subsection{Burial of dogs at localities of the Roman and Migration Periods and their interpretation}

The issue of the burial of dogs at settlements of the Roman Period has been addressed by Beneš and Nývltová Fišáková (2009, 531-542), who mapped 25 localities in Bohemia with findings of complete skeletons of dogs or parts thereof. According to the authors, the occurrence of dog burials corresponds with population density, and dog skeletons are most often found in sunken huts, housing pits and kilns throughout the entire Roman Period from its very beginning until its end (Beneš, Nývltová Fišáková 2009, 534-536). There is no evidence of a similar treatment of dog's remains in the Czech Republic in the chronologically-adjoining epochs before and after, i.e. La Tène and the Migration Period (Beneš, Nývltová Fišáková 2009, 536). There are only sporadic findings from burial grounds known from the Migration Period. In Plotiště nad Labem (dist. Hradec Kralové), a chamber grave was uncovered, oriented on an east-west axis and defined by a rectangular gutter, with an older man, and a 14-year-old-or-so boy and five skeletons of dogs. One dog was lying on the floor beneath the skeleton of the man, the other four dogs rested with the boy in the burial chamber (Rybová 1967, 632; Droberjar 2002, 244; Nácarová

Table 6. Radiocarbon dating of animal bones.

\begin{tabular}{llcc}
\hline \multicolumn{2}{c}{ OxCal v4.2.3 Bronk Ramsey (2013); r:5; IntCal13 atmospheric curve (Reimer et al. 2013) } \\
\hline I.D. & Sample & ${ }^{14}$ C age & 1 sigma \\
\hline Poz-64644 & Medium mammal - long bone & $1505 \pm 30 \mathrm{BP}$ & 540AD to 601AD \\
Poz-64646 & Medium mammal - long bone & 1970 $\pm 30 \mathrm{BP}$ & 431AD to 635AD \\
\hline
\end{tabular}


2011, 20). In the skeletal grave of a warrior in Konobrže (dist. Most), oriented east-west, was found the skeleton of a dog located at the feet of the deceased (Svoboda 1965, 249250). On the burial ground in Šakvice (dist. Břeclav) there is some evidence cited of a dog burial in a horse doublegrave (obj. no. 42; Droberjar 2002, 322), but according to the osteological determination, the skeletal remains of the dog were found in feature no. 4 , along with three specimens of horses (Kratochvíl 1980, 55).

In Moravia, dog burials have been found at settlements of the Roman Period in: sunken huts in Blučina (Droberjar 1997, 25); Brno-Starý Lískovec, where three complete skeletons were found (Peške 1978, 125; Víchová 2003, 291); in Křepice, Ladná (Tejral 1974, 53); Vyškov (Šedo 2004, 473); Rajhrad (Peškař 1975, 39; Droberjar 1997, 26); Vrchoslavice (Dreslerová 2006, 228-229) and in a clay pit in Pasohlávky (Šedo 1999, 275). In Skalice nad Svitavou, a dog skeleton was found at the entrance to the settlement feature, and a second incomplete skeleton was discovered in a storage pit (Staňková 2008, 39-40). In Tvarožná, in the pre-kiln chamber of a pottery kiln, there was found the lower jaw of a dog, which had been inserted there after the end of the kiln's operation (Mikulková 1996, 181). A similar finding, this time a complete skeleton of a dog, was found at the mouth of a pit furnace in Kozlany (Michna 1993, 412).

Another interesting finding, which corresponded with the Zličín finding by its location in outside facilities (cottages, kilns) and a settlement or a funerary complex, was made in Mořice (Beneš 2006, 62-64). In the circular feature no. 506, with a diameter of $1.2 \mathrm{~m}$ and depth of $0.5 \mathrm{~m}$ (Beneš 2006, 27) close to a stream, a skeleton of a dog in the anatomical position was found, resting on its left side, with the skull to the west and limbs to the north. The author believes that due to the placing of the skeleton in the forefront of the settlement, there arose the idea that this "guardian" or "sacrifice" refers to the entire settlement. According to the author, the symbolism of leaving the dog's head turned to the west is obvious, for it may also point to the importance of the stream in the lives of the settlement's residents. Unfortunately, it was not determined whether the dog was buried at the beginning of the settlement, when it could be some kind of construction sacrifice with the mission to protect the settlement, or whether it was buried when the residents were leaving (Beneš 2006, 63-64). However, conclusions of this kind are difficult to support with only certain specific evidence.

Findings of dog skeletons are most often interpreted as "construction sacrifices" (in the case of deliberately-killed dogs) or as "guardians" (in the case of natural death). Dogs that are found buried together with the deceased function as guides to the underworld, or they were the favourite pet of the owner (Makiewicz 1987, 248; Podborský 2006, 453).

O. Šedo $(2004,473)$ has taken into account a wide range of interpretive possibilities: random coincidence; individual people's relationship with an animal; carcass cleaning; disposal of an animal (and its parts) that died due to illness; or a manipulation within non-economical actions. The last stated option, where it is necessary to anticipate the inclusion of the observed phenomena within some cult act, requires the most caution. The settlement environment could generate archaeologically-documentable situations where confusion between profane and ritualistic behaviour cannot be ruled out.

The author also mentions other ideas from various archaic cultures, ideas other than where a dog is associated with protection and guard functions, and emphasizes their reputed connection with death and the world of the dead; these ideas were, of course, also included in the circle of protectors of home and fire. However, he himself does not much agree with interpretations according to which the dogs were, for instance, fictive guardians or construction sacrifices, because a substantial number of these dogs were apparently only placed into the houses after the end of their function. He therefore suggests that a significant part of the burial of animals in unusual situations at settlements could be linked to cult practices: practices related to the closure of a building's existence and the ending of a building's functions of production and agriculture. In these cases, the dog, or other animal, functioned more as a "scapegoat" to which all the evil was laid down, and which would otherwise threaten future construction on the same site; thus the links between the past and the future were supposed to be broken in this way (Šedo 2004, 474-475; Šeiner 2013, 62).

As an alternative to these interpretations, it is even possible to try to join them together in a kind of synthesis. There is no reason to separate the "guardian" function of the $\mathrm{dog}$, its association with the underworld and death, or the association of dog burials with the decay phase of buildings. If we combine these cases of dog burials with the possible interpretation of some of the findings of human remains in settlement features (and often at the time of their ending) with a kind of "taboo" for the deceased's property, or a specific part of it (which could also include their house or workshop), then the buried dog could perform all three functions simultaneously. With the death of a particular person (accompanied, perhaps, by some unusual circumstances or signs) the survivors could decide to abandon a certain feature that was strongly associated with the deceased person during their life. Into such an abandoned feature, the person on their own could then be buried or their dog (or a person with the dog), so that the dog would guard against any intruders who might disrupt the peace of the dead, or their property. This hypothesis is very problematic and hard to prove; however, it at least attempts to explain why the function of the majority of features with the burial of a dog or a human in an involution phase, which according to the above interpretation should cleanse and prepare the feature for reuse, was never restored (Šeiner 2013, 62-63).

\subsection{Animal bones from graves}

The animal species present and the composition of the assemblage fits well with the region and for an interval spanning from the Roman period to Early Middle Ages (e.g. Pleinerová 1965; 1975; Kyselý 2000; Kovačiková 2003). 
Nevertheless, due to the uncertain dating of the finds, the following discussion of possible subsistence issues should only be taken as a working hypothesis. On the Vinařická burial ground in Prague-Zličín, several common types of domestic animals - cattle, pig and sheep/goat - were found. The bones of wild animals are rare, but this is usually considered to reflect the hunting activity (Dreslerová et al. 2013). The osteological evaluation of skeletal remains from the Migration Period settlement of Březno u Loun showed that the largest percentage of bones belonged to cattle, pig and sheep/goat. Hunting fauna was represented by red deer and roe deer. Dogs were also quite common. Findings of horse, chicken, and cat bones were very rare (Pleinerová $1965,499)$. Due to the sporadically-published evaluations of animal bones from this period, it is necessary to focus on the chronologically-adjoining periods before and after, i.e. the Roman and Slavic period. In the Roman period, the most important livestock was cattle, pig, and sheep/ goat (Kratochvíl 1980; Peške 1994; 1996). Often there are also found bones of a horse or chicken (Peške 1978; 1994; Vachůtová 2003-2004; Uhlírová 2015). The hunting fauna is minimally represented, which indicates that the hunt did not constitute a primary source of livelihood, but served to replenish the resource base (fur, leather, solid antler; Vachůtová 2003-2004, 114). The typical domestic animals of the Early Middle Ages are cattle, pig and sheep/goat (Chrzanowska, Krupska 2003; Kovačiková 2003; Uhlírová et al. 2012). The largest representation of cattle bones (61\%) was recorded at the Sand Fort in Raabs an der Thaya in Lower Austria (Pucher, Schmitzberger 1999). The analysis of animal bones from Březno u Loun shows that in the early Slavic period, the bones of cattle prevail over pig bones, but during the $8^{\text {th }}$ and $9^{\text {th }}$ century their numbers became equal (Pleinerová 1975; Beranová 1980; Kyselý 2000). The hunting fauna constituted only an additional source of livelihood (Kyselý 2000; Miklíková 2010).

\section{Conclusion}

The zooarchaeological analysis of the bones from the burial ground in Prague-Zličín has led to the following conclusions:

A dog (presumably female), $62 \mathrm{~cm}$ in height at the withers, was placed in feature no. 1524, in the anatomical position. From the state of the teeth it was deducted that it was an older dog whose age might have been the cause of death. However, blood poisoning, caused by a fracture of the lower canine, cannot be ruled out either. There were no traces of human intervention detected on the dog's bones. From the circumstances of the finding we conclude that the dog was deliberately, and without any box, placed into the peripheral part of a shallow, but relatively long and regular, pit that primarily served for this purpose. The dog was not placed in a secondarily-utilized feature, i.e. extinct residential or industrial premises, as were some of the above examples. The dating of the dog's skeleton, conducted using ${ }^{14} \mathrm{C}$ introduced a surge of interest into this finding, as it was correlated with the skeleton burial ground from the Migration Period. The time correlation between the burial ground and the separated burial pit for the dog, and the way of its placement drew our attention to an unknown phenomenon. But to make a clear cultural and historical interpretation of the finding is problematic. From the point of view of its position, we cannot evaluate this finding as a dog burial in the burial ground. The feature with the dog is not part of the burial ground, and its distance from the nearest grave is at least 96 metres. The archaeological situation in the opposite direction from the feature, i.e. outside the excavated area, is unknown. However, the feature was found near the edge of the historical core of the medieval village Zličín, which is located at the site of several springs. In the vicinity of these important water sources, we can assume the position of a settlement pertaining to the burial ground. It is therefore more likely that the feature of the burial of the dog is related to the anticipated settlement, rather than to the burial ground. Thus the importance of this dog burial lies in the fact that it serves as an important clue for locating the settlement of the creators of the significant burial ground from the Migration Period in Prague-Zličín.

In the infill of the human graves the animal bones belong mainly to domestic fauna, especially cattle, pig and sheep/ goat; hunting fauna is represented only sporadically. The studied material is extensively damaged and fragmentary, which might point to the damaging erosion/abrasion (due to exposure to weathering and/or transport within sediments) in addition to the severe physical environment (the chemistry and high moisture content of the soil/sediment). The material seems to represent mixed household waste without any particular preference for certain anatomical parts of the skeleton. However, due to the archaeological dating of the cultural material and the high rodent activity, we cannot be sure that the faunal remains date to the Migration Period and originate from a (yet unknown and nearby) settlement contemporary with the burial ground.

\section{Acknowledgment}

This work was supported by the Czech Science Foundation, project number P405 / 13-189 55S Natural environment, health and mobility - a multidisciplinary approach to the study of a burial ground of the Migration Period.

\section{References}

BERANOVÁ, M. 1980: Zemédělství starých Slovanů. Praha.

BENEŠ, Z. 2006: Sídliště z pozdní doby rrímské v Mořicích. MS. Master diploma thesis. Deposited: Library of the Faculty of Arts, Masaryk University, Brno.

BENEŠ, Z., NÝVLTOVÁ FIŠÁKOVÁ, M. 2009: „Pohřby psư“ na sídlištích doby ř́mské v Čechách: současný stav poznání. In: Karwowski, M., Droberjar, E. (Eds.): Archeologia Barbarzyńców 2008: powiazania $i$ kontakty $w$ świecie barbarzyńskim. Materiały z IV Protohistorycznej Konferencji Sanok, 13-17 października 2008, Collectio Archaeologica Ressoviensis Tomus XIII, Rzeszów, 531-542. 
ČERVENÝ, Č., KOMÁREK, V., ŠTĚRBA, O. 1999: Koldi̊v atlas veterinárni anatomie. Praha.

DRESLEROVÁ, G. 2006: Bronze- und römerzeitliche Tierknochenfunde aus Vrchoslavice (kreis Prostějov). Ve službách archeologie 7, 227-230.

DRESLEROVÁ, G., HAJNALOVÁ M., MACHÁČEK, J. 2013: Subsistenční strategie raně středověkých populací v dolním Podyjí. Archeozoologické a archeobotanické vyhodnocení nálezů z výzkumu Kostice - Zadní hrúd (2009-2011). Archeologické rozhledy LXV, 4, $825-850$.

DRIESCH von den, A. 1976: A Guide to the Measurement of Animal Bones from Archaeological Sites. Cambridge.

DRIESCH von den, A., BOESSNECK, J. 1974: Kritische Anmerkungen zur Widerristhöhenberechnung aus Längenmaßen vor- und Frühgeschichtlicher Tierknochen, Säugetierkundliche Mitteilung 22, 325-348.

DROBERJAR, E. 1988: Sídliště z doby římské ve Vlčnově - Dolním Němčí a projevy římského impéria ve svébském Pomoraví. MS. Student thesis. Deposited: Library of the Faculty of Arts, Masaryk University, Brno.

DROBERJAR, E. 1997: Studien zu den germanischen Siedlungen der älteren römischen Kaiserzeit in Mähren. Fontes archaeologici Pragenses 21. Praha.

DROBERJAR, E. 2002: Encyklopedie ř́mské a germánské archeologie v Čechách a na Moravě. Praha.

FRANCE, L. D. 2009: Human and Nonhuman Bone Identification. A Color Atlas. Boca Raton.

CHRZANOWSKA, W., KRUPSKA, A. 2003: Tierknochenfunde aus dem Suburbium des Burgwalls von Mikulčice. In: Poláček. L. (Ed.): Studien zum Burgwall von Mikulčice 5, Archäologisches Institut der Akademie der Wissenschaften der Tschechischen Republik, Brno, 109-119.

JIŘíK, J., VÁVRA, J. 2015: Zbraně, zbroj, nástroje a predměty denní předměty. In: Jiř́ík, J., Vávra, J., Šmolíková, M., Kuchařík, M. et al.: Hroby barbarů v Praze Zličině. Svět živých a mrtvých doby stěhováni národi̊, Praha, 170-179.

JIŘÍK, J., VÁVRA, J., ŠMOLÍKOVÁ, M., KUCHAŘÍK, M. et al. 2015 Hroby barbarư v Praze Zličině. Svět živých a mrtvých doby stěhováni národů. Muzeum hlavního města Prahy, Praha.

KOVAČIKOVÁ, L. 2003: Toušeň-Hradiško: Analýza zviřecích kostí ze sondy 1/2001 (raný středověk). Archeologie ve středních Čechách 7 , 531-539.

KRATOCHVÍL, Z. 1980: Zviřrecí kostní materiál ze sídlišt’ doby římské. Přehled výzkumů 1977, 53-54.

KYSELÝ, R. 2000: Archeozoologický rozbor osteologického materiálu z lokality Rubín a celkový pohled na zviřrata doby hradištní. Památky archeologické 91, 155-200.

LYMAN, R. L. 1994: Vertebrate Taphonomy. Cambridge.

MAKIEWICZ, T. 1987: Znaczenie sakralne tak zwanych „pochówków psów" na terenie środkowoeuropejskiego barbaricum. Folia praehistorica Posnaniensia 2, 239-277.

MICHNA, P. 1993: Přehled archeologických výzkumů na Moravě a ve Slezsku za rok 1992. Vlastivědný věstník Moravský 45/4, 408-415.

MIKLÍKOVÁ, Z. 2010: Archeozoologické nálezy zo stredovekého sídliska v Bajči. Slovenská archeológia 58, 1, 123-168.

MIKULKOVÁ, B. 1996: Hrnčířská pec z doby římské z Tvarožné, okr. Brno-venkov. Pravěk Nová rada 6, 175-186.

NAJBRT, R. 1980: Veterinární anatomie 1. Praha.

NÁCAROVÁ, J. 2011: Hroby vinařického stupně z doby stěhování národů. MS. Bachelor diploma thesis. Deposited: Library of the Faculty of Arts, University of West Bohemia, Pilsen.

PEŠKAǨ, I. 1975: Druhá chata z doby ř́mské na sídlišti v Rajhradě (okr. Brno-venkov). Přehled výzkumů 1974, 39-40.

PEŠKE, L. 1976: Osteologické nálezy z Prahy-Michle. Archeologické rozhledy $28,156-159$.

PEŠKE, L. 1978: Nálezy kostí z výzkumu ve Starém Lískovci (okr. Brnoměsto). Přehled výzkumů 1976, 125-126.

PEŠKE, L. 1990: Osteologický materiál ze sídliště straší doby římské v Kolíně-Radovesnicích. Archeologické rozhledy 42/3, 282-283.

PEŠKE, L. 1994: Osteologické nálezy z Mlékojed okr. Mělník, ze starši doby ř́mské. Archeologické rozhledy 46/2, 306-318.

PEŠKE, L. 1996: Určení osteologického materiálu z pece u Tvarožné. Pravěk Nová rada 6/1996, 187-188.
PLEINEROVÁ, I. 1965: Výzkum osady z doby stěhování národů a doby slovanské v Březně u Loun. Archeologické rozhledy 17, 495-500, 509$515,517-529$

PLEINEROVÁ, I. 1975: Březno. Vesnice prvních Slovanův severozápadních Čechách. Praha.

PODBORSKÝ, V. 2006: Náboženství pravěkých Evropanů. Brno.

PUCHER, E., SCHMITZBERGER, M. 1999: Ein mittelalterlicher Fundkomplex aus Niederösterreich mit hohem Wildanteil: Die Flur Sand bei Raabs a. d. Thaya. In: Becker, C., Manhart, H., Peters, J., Schibler, J. (Eds.): Historia Animalium ex Ossibus. Beiträge zur Paläoanatomie, Archäologie, Agyptologie, Ethnologie und Geschichte der Tiermedizin. Internat. Arch. 8. Stud. Honoraria. Rahden/Westf., 355-378.

REITZ, J. E., WING, S. E. 2008: Zooarchaeology. Cambridge.

PROCHÁZKA, Z. 1994: Chov psů. Státní zemědělské nakladatelství. Praha.

REIMER, P. J., BARD, E., BAYLISS, A., BECK, J. W., BLACKWELL,

P. G., BRONK RAMSEY, C., GROOTES, P. M., GUILDERSON,

T. P., HAFLIDASON, H., HAJDAS, I., HATTE, C., HEATON, T.

J., HOFFMANN, D. L., HOGG, A. G., HUGHEN, K. A., KAISER,

K. F., KROMER, B., MANNING, S. W., NIU, M., REIMER, R. W., RICHARDS, D. A., SCOTT, E. M., SOUTHON, J. R., STAFF, R. A., TURNEY, C. S. M., VAN DER PLICHT, J., 2013. IntCal13 and Marine13 radiocarbon age calibration curves $0-50,000$ years cal BP. Radiocarbon 55, 1869-1887.

RYBOVÁ, A. 1967: Výzkum pohřebiště z mladší doby římské a počátku stěhování národů v Plotišstích n. L. Archeologické rozhledy 19, 631-643.

SCHMID, E. 1972: Atlas of Animal Bones for Prehistorians, Archaeologists and Quaternary Geologists. Amsterdam-London-New York.

STAŇKOVÁ, L. 2008: Germánská osada $\mathrm{z}$ doby římské ve Skalici nad Svitavou. MS. Bachelor diploma thesis. Deposited: Library of the Faculty of Arts, Masaryk University, Brno.

SVOBODA, B. 1965: Čechy v době stěhování národi̊. Praha.

ŠÁLKOVÁ, T., D DOHNALOVÁ, A., NOVÁK, J., HILTSCHERD, T., JIŘÍK, J., VÁVRA, J. 2016: Unrecognized taphonomy as a problem of identification and the scale of contamination of archaeobotanical assemblages - the example of Prague - Zličín Migration Period burial ground. Interdisciplinaria Archaeologica, Natural Sciences in Archaeology, VII/1/2016.

ŠEDO, O. 1999: Pasohlávky (okr. Břeclav). Přehled výzkumů 1997-1998, 275.

ŠEDO, O. 2004: K výkladu nálezů koster zvířat na sídlišti z doby římské ve Vyškově. In: Kazdová, E. Měřínský, Z., Šabatová, K. (Eds.): K poctě Vladimíru Podborskému. Brno, 473-478.

ŠEINER, J. 2013: Archeologické doklady náboženství starých Germánů ve střední Evropě. MS. Master diploma thesis. Deposited: Library of the Faculty of Arts, Masaryk University, Brno.

TEJRAL, J. 1974: Další výzkumy na sídlišti z doby římské v Ladné (okr. Břeclav). Přehled výzkumů 1973, 53-54.

UHLÍŘOVÁ, H., DRESLEROVÁ, G., NÝVLTOVÁ FIŠÁKOVÁ, M., IVANOV, M. 2012: Osteologický výzkum materiálu z Pohanska Jižního předhradí (1991-1994): Srovnání s raně středověkými lokalitami. Geologické výzkumy na Moravě a ve Slezsku XIX, 1-2, 63-66.

UHLÍŘOVÁ, H. 2015: Archeozoologické zpracování materiálu ze sídliště doby ř́mské z Hrušovan Brna. Pravěk Nová rada 22, 312-326.

VACHŮTOVÁ, D. 2003-2004: Brněnsko v době ř́mské. Sbornik praci Filozofické fakulty brněnské univerzity M 8-9, 111-189.

VÁVRA, J., JIŘÍK, J., KUCHAŘÍK, M., KUBÁLEK, P. 2009: Výzkum pohřebiště z doby stěhování národů v Praze-Zličíně v letech 2005-2008. Archaeologica Pragensia 19, 209-230.

VÁVRA, J., JIŘÍK, J., KUCHAŘÍK, M., JAROŠOVÁ, I., VÍŠKOVÁ, M., KUBÁLEK, P. 2012: The Migration Period Burial Site in Prague-Zličín, Czech Republic. Preliminary report. Zeitschrift für Archäologie des Mittelalters 40, 1-25.

VÍCHOVÁ, D. 2003: Sídliště z mladší doby římské v Brně-Starém Lískovci. Pravěk Nová rada 2002/12, 271-318.

VÍŠKOVÁ, M., JAROŠOVÁ, I., JIŘÍK, J., VÁVRA, J., KUCHAŘÍK, M. 2012: Populace $\mathrm{z}$ doby stěhování národů $\mathrm{z}$ pohřebiště v Praze - Zličíně z pohledu fyzické antropologie. Sborník Národního muzea v Praze, rada A 66/3-4, 61-70.

WAGNER, K. 1930: Rezente Hunderasse. Eine osteologische Untersuchung. Skrifter utgitt av det norske Videnskaps-akademi i Oslo. I. Matematisknaturwidenskapelig klasse 9, Oslo. 